\title{
Effects of the Soil-Derived Microorganism BX-1 on Chicken Newcastle Disease
}

\author{
Kiyotaka Murakami1 ${ }^{12 *}$, Kazuhide Adachi ${ }^{*}$, Retno Damajanti Soejoedono ${ }^{3}$, \\ Ekowati Handharyani ${ }^{3}$, Yasuhiro Tsukamoto ${ }^{1 \#}$ (D)
}

\author{
${ }^{1}$ Department of Animal Hygiene, Graduate School of Environmental \& Biological Sciences, Kyoto Prefecture University, \\ Kyoto, Japan \\ ${ }^{2} \mathrm{R} \& \mathrm{D}$ Section, Taiga Inc., Tokyo, Japan \\ ${ }^{3}$ Faculty of Veterinary Medicine, Bogor Agriculture University, Bogor, Indonesia \\ Email: "ytsuka@kpu.ac.jp
}

How to cite this paper: Murakami, K., Adachi, K., Soejoedono, R.D., Handharyani, E. and Tsukamoto, Y. (2020) Effects of the Soil-Derived Microorganism BX-1 on Chicken Newcastle Disease. Advances in Infectious Diseases, 10, 1-10.

https://doi.org/10.4236/aid.2020.101001

Received: December 28, 2019

Accepted: January 19, 2020

Published: January 22, 2020

Copyright (C) 2020 by author(s) and Scientific Research Publishing Inc. This work is licensed under the Creative Commons Attribution International License (CC BY 4.0).

http://creativecommons.org/licenses/by/4.0/

\begin{abstract}
In recent years, effective microorganisms (EMs) have been administered to humans and domestic animals, and their usefulness has been recognized for promoting health and enhancing immunity. For example, the preventative effects against flu are enhanced by ingestion of Lactobacillus by humans, and symptom relief of atopic dermatitis has been reported, with EMs actually used in commercial products. In addition, EM preparations are being used in livestock to prevent infections (e.g. Salmonella and Escherichia coli infection). In poultry, avian influenza and Newcastle disease are terrible and fatal infectious diseases that cause significant economic damage. Furthermore, countries designated as contaminated with these pathogens can experience major trade problems. Given the above, how to protect livestock from infections safely and at low cost without using disinfectants, antibiotics and vaccines is a major issue. In the present study, we examined whether or not Newcastle disease could be suppressed by feeding chickens BX-1 as an EM feed. A field strain of Newcastle virus was cloned from cloaca swabs of large numbers of dying chickens in a poultry farm in Indonesia by polymerase chain reaction (PCR) and hemaggregation assays. Chicken kidney cells and embryonated eggs were highly sensitive to this virus, and high titers of virus were able to be collected. The experimental viral inoculated to chickens showed a high mortality rate, with high pathogenicity in birds. Conventional chickens were also raised on a diet supplemented with BX-1 and directly infected with the Newcastle virus. The mortality was decreased in these infected birds. Even the low dose of BX-1 had an inhibitory effect on the lethality of the infection. These results suggest that $\mathrm{BX}-1$ intake through an EM diet is effective in controlling Newcastle disease.
\end{abstract}




\section{Keywords}

Newcastle Disease, Effective Microorganisms, BX-1, Chicken

\section{Introduction}

Newcastle disease (ND) is a viral infection to which various species of bird, including poultry, are susceptible [1]. ND outbreaks occur in many countries, including Japan, and the disease is highly contagious exerting a significant economic impact. In Japan, ND is designated an infectious diseases under the livestock infectious disease prevention law for chickens, ducks, quails and turkeys [2]. Other infectious diseases mentioned in this law for poultry include highly pathogenic avian influenza, poultry cholera and salmonella infections.

ND was first discovered in 1926 in Southeast Asia but only named when it was rediscovered in 1927 in Newcastle upon Tyne, UK. The pathogen ND virus (NDV) is a single-stranded RNA virus classified into the Paramyxoviridae family along with measles virus, mumps virus, distemper virus, Sendai virus and others. NDV infection occurs through feed, water, equipment and clothing contaminated with feces of affected birds [3]. Symptoms vary greatly depending on the NDV strain, host species, health status and age, among other factors, but common symptoms include those of the respiratory system (dyspnea, cough) and nervous system (depression, loss of appetite, wing weakness, paralysis), swelling of the eyes and neck, diarrhea, abnormal egg shells and decreased egg production [4].

NDV strains are divided into highly toxic, addictive and attenuated strains. The highly toxic type is further divided into an Asian type and an American toxic type [1]. Severely virulent strains cause serious respiratory and neurological symptoms, are highly infectious and have a mortality rate of over $80 \%$. Addictive strains cause coughing and egg-laying abnormalities, resulting in a mortality rate of about $10 \%$. The mortality of attenuated strains is negligible. Since the countries that use ND vaccines are designated as contaminated countries, their export of poultry products, such as chicken and eggs, to clean countries, such as the USA and Canada, is not permitted. If a novel ND prevention method could be developed instead of a vaccine, the livestock industry would benefit from a trade perspective.

We established a virus infection prevention method using ostrich antibodies instead of vaccines and antibiotics [5] [6]. In the present study, we attempted to control the viral infection in chickens using effective microorganisms (EMs), a feed additive. In humans, yogurt and beverages containing Lactobacillus stabilize the intestinal microflora and suppress the colonization of pathogens, relieve symptoms of atopic dermatitis and block pathogen infection by enhancing immunity [7] [8] [9] [10]. In livestock, various EM agents are used to promote growth and prevent infectious diseases. In chickens, microbial competitive ex- 
clusion has been set for preventing food poisoning caused by Salmonella and $E$. coli [11] [12] [13].

As a probiotic, the mixed microorganism agent BX-1, which is mainly composed of Lactobacillus and yeasts removed from soil, has been commercialized (Kawashima Co., Ltd.) [14]. Since BX-1 is a mixture of soil microorganisms, it does not seem to exert the same effect as the natural intestinal microflora; nevertheless, it can still be expected to be useful as a member of the bacterial microflora with many physiological activities that can benefit the living body. BX-1 is a group of aerobic bacteria, and since it is in a dry powder form, it is easy to handle and inexpensive. BX-1 has been suggested not only to suppress the colonization of intestinal pathogens, such as Salmonella and Escherichia coli, but also to enhance the vitality of the living body, particularly the immunity.

We herein report the results of our infection experiment using a highly pathogenic field strain of NDV obtained from a poultry farm in Indonesia.

\section{Materials and Methods}

\section{Newcastle disease virus $(N D)$}

Swab samples from the cloaca of dying chickens on an Indonesia poultry farm were analyzed. RNA was extracted from the chorioallantoic fluid (CAF) of embryonated chicken eggs and culture media of chicken kidney cells inoculated with the swab samples and ND vaccine strain using a viral RNA extraction kit. Mixtures of $2 \mu \mathrm{L}$ of RNA, $1 \mu \mathrm{L}$ of 5 -pmol oligo (dT), $4 \mu \mathrm{L}$ of $5 \times$ RTbuffer, $2 \mu \mathrm{L}$ of $10 \mathrm{mM}$ dNTPs, $1 \mu \mathrm{L}$ of Rever-Tra Ace and $10 \mu \mathrm{L}$ of DEPC water were reverse-transcribed at $42^{\circ} \mathrm{C} ; 60$ minutes, $99^{\circ} \mathrm{C} ; 5$ minutes and further, $15^{\circ} \mathrm{C}$. Polymerase chain reaction (PCR) was carried out using cDNA, $2 \mu \mathrm{l}$ of the cDNA, $12.5 \mu \mathrm{l}$ of $2 \times$ pre-mix Taq, $9.5 \mu \mathrm{l}$ of sterilized distilled water and $1 \mu \mathrm{l}$ of NDV F1/M1 primer (F1: 5' CAT-CTT-CCC-AAC-TGC-CAC-TG 3', M1: 5' TTC-TCTAGC-AGT-GGG-ACA-GC 3') [2] under the following conditions: $94^{\circ} \mathrm{C}$ for 7 minutes and 34 amplification rounds at $94^{\circ} \mathrm{C}$ for 30 seconds, $55^{\circ} \mathrm{C}$ for 1 minute and $72^{\circ} \mathrm{C}$ for 1 minute, annealing at $72^{\circ} \mathrm{C}$ for 7 minutes and then held at $4{ }^{\circ} \mathrm{C}$. The PCR product was used for electrophoresis on an agarose gel with a 100-bp ladder.

\section{Hemaggregation test}

The blood samples from chickens were mixed with an equal volume of Alseba solution and centrifuged at $2000 \mathrm{rpm}$ for 7 minutes. The supernatant was removed, and Alseba solution was added again; the mixture was then centrifuged at $2000 \mathrm{rpm}$ for $7 \mathrm{~min}$. The washed blood cells were added to phosphate-buffered saline (PBS) to prepare an erythrocyte solution. The serial dilution of virus solution of the NDV vaccine and farm strain was added to a round-bottom 96-well microplate, and then prepared erythrocytes were placed in each well and incubated at room temperature with pre-immune antibody or anti-NDV antibody for 45 minutes.

\section{Infection experiments in chicken kidney cells}


The viral solution of NDV farm strain in Dulbecco's modified medium was added to chicken kidney cells (CKs), and the cytopathic effect (CPE) in the cultures was examined at $48 \mathrm{~h}$ post-viral inoculation.

Infection experiment in embryonated eggs

A $100-\mu \mathrm{L}$ aliquot of the virus solution of NDV farm strain was injected into the 10-day-old embryonated eggs, and viability was judged $72 \mathrm{~h}$ later. The CAF was sampled and used for the in vivo infection examination in chickens.

NDV infection experiment using chickens

Ten white Leghorn male chicks at 10 days old were inoculated intranasally with $8 \mathrm{HA}$ of NDV farm strain. The birds were raised under free water and feeding conditions in a BSL-2 facility, and the mortality rate was confirmed by the 10th day. For histopathology, the organs were removed from dying chickens, fixed in formalin, embedded in paraffin, sectioned at $3 \mu \mathrm{m}$ and stained with Hematoxylin-Eosin (HE) according to the conventional method. Thereafter, the sections were examined under a microscope.

Effects of $B X-1$ intake in chickens infected with NDV farm strain

BX-1 powder mixed at $0.02 \%, 0.2 \%$ and $2 \%(\mathrm{w} / \mathrm{w})$ in commercial chicken formula feed was fed to 10-day-old white leghorn chickens. Over 10 individuals were used for each BX-1 formulation dose. As control animals, other chickens were fed the same commercial diet without BX-1 powder $(0 \%)$. At one week of BX-1 feeding, $8 \mathrm{HA}$ of the NDV farm strain was been inoculated intranasally into each chicken. These animals were raised under free water and feeding conditions in a BSL-2 facility, and the mortality rate was confirmed by the 10 th day.

\section{Results}

\section{Organisms in $B X-1$}

The species of organisms in BX-1 were confirmed by a third-party laboratory in Japan and listed in Table 1. Various microorganisms were found in BX-1, with the Staphylococcus group dominant.

\section{Newcastle virus}

Embryo deaths were observed in all of the eggs inoculated with cloaca swabs of dying chickens from an Indonesian poultry farm. In addition, when inoculated into CK, the typical CPE appeared in culture cells. PCR using primers specific to NDV showed that the pathogen obtained from the chicken farm in Indonesia was Newcastle virus: An assumed 957-bp single band was detected in both the farm samples and vaccine strain used as a positive control (Figure 1). In addition, the solution from farm could aggregate the chicken erythrocytes which were inhibited by the addition of anti-NDV antibody (Figure 2). Over $80 \%$ of chickens died following intra-nasal inoculation of the CAF. Histopathologically, ND-specific findings, such as severe acute pneumonia and tracheitis, myocarditis and acute enteritis, were observed (Figure 3). Accordingly, the pathogens obtained from the Indonesian poultry farm were confirmed to be a highly pathogenic strain of NDV. 
Table 1. Micro-organisms in BX-1.

\begin{tabular}{|c|c|c|}
\hline Taxon name & colony Count/dish & Proportion (\%) \\
\hline Staphylococcus saprophyticus group & 12,400 & 59.5524 \\
\hline Staphylococcus kloosii & 6787 & 32.5953 \\
\hline Weissella paramesenteroides group & 432 & 2.0747 \\
\hline Staphylococcus aureus group & 272 & 1.3063 \\
\hline Kocuria koreensis & 246 & 1.1814 \\
\hline Staphylococcus pettenkoferi group & 148 & 0.7108 \\
\hline Bacillus cereus group & 110 & 0.5283 \\
\hline Leuconostoc pseudomesenteroides group & 67 & 0.3218 \\
\hline Pediococcus acidilactici group & 24 & 0.1153 \\
\hline Kocuria kristinae & 19 & 0.0912 \\
\hline Staphylococcus sciuri group & 15 & 0.0720 \\
\hline Corynebacterium variabile group & 14 & 0.0672 \\
\hline Enterococcus italicus group & 14 & 0.0672 \\
\hline Brachybacterium faecium group & 11 & 0.0528 \\
\hline Brevibacterium DL489154_s & 10 & 0.0480 \\
\hline Leuconostoc mesenteroides group & 8 & 0.0384 \\
\hline Corynebacterium nuruki group & 7 & 0.0336 \\
\hline Citricoccus muralis group & 5 & 0.0240 \\
\hline Corynebacterium flavescens & 4 & 0.0192 \\
\hline Corynebacterium minutissimum group & 4 & 0.0192 \\
\hline Enterococcus faecium group & 4 & 0.0192 \\
\hline Bacillus megaterium group & 3 & 0.0144 \\
\hline Lactobacillus acidipiscis & 3 & 0.0144 \\
\hline Lactococcus lactis group & 3 & 0.0144 \\
\hline Actinomyces slackii & 2 & 0.0096 \\
\hline Arthrobacter agilis group & 2 & 0.0096 \\
\hline Arthrobacter echini & 2 & 0.0096 \\
\hline Blautia wexlerae & 2 & 0.0096 \\
\hline Clavibacter michiganensis group & 2 & 0.0096 \\
\hline Kocuria rhizophila group & 2 & 0.0096 \\
\hline Neomicrococcus lactis & 2 & 0.0096 \\
\hline Ruminococcus faecis & 2 & 0.0096 \\
\hline Actinomyces provencensis group & 1 & 0.0048 \\
\hline Anaerostipes hadrus group & 1 & 0.0048 \\
\hline Bacillus carboniphilus group & 1 & 0.0048 \\
\hline Bacillus smithii & 1 & 0.0048 \\
\hline Bifidobacterium adolescentis group & 1 & 0.0048 \\
\hline Blautia faecis & 1 & 0.0048 \\
\hline Brevibacterium iodinum group & 1 & 0.0048 \\
\hline
\end{tabular}




\section{Continued}

\begin{tabular}{|c|c|c|}
\hline Caenibacillus caldisaponilyticus & 1 & 0.0048 \\
\hline Caldibacillus debilis & 1 & 0.0048 \\
\hline Corynebacterium tuberculostearicum & 1 & 0.0048 \\
\hline Corynebacterium xerosis group & 1 & 0.0048 \\
\hline Dorea formicigenerans & 1 & 0.0048 \\
\hline Enterococcus saccharolyticus group & 1 & 0.0048 \\
\hline Fusicatenibacter saccharivorans & 1 & 0.0048 \\
\hline Geobacillus stearothermophilus group & 1 & 0.0048 \\
\hline Geobacillus thermoleovorans group & 1 & 0.0048 \\
\hline Geobacillus toebii group & 1 & 0.0048 \\
\hline Kurthia zopfii group & 1 & 0.0048 \\
\hline Lactobacillus dextrinicus & 1 & 0.0048 \\
\hline Lactobacillus sakei group & 1 & 0.0048 \\
\hline Lactococcus taiwanensis & 1 & 0.0048 \\
\hline Listeria grayi & 1 & 0.0048 \\
\hline Dorea PAC000479_s & 1 & 0.0048 \\
\hline Sporobacter PAC001162_s & 1 & 0.0048 \\
\hline Sporobacter PAC001306_s & 1 & 0.0048 \\
\hline PAC001201_g PAC002029_s & 1 & 0.0048 \\
\hline Romboutsia timonensis & 1 & 0.0048 \\
\hline Rummeliibacillus pycnus & 1 & 0.0048 \\
\hline Staphylococcus succinus group & 1 & 0.0048 \\
\hline Weissella ghanensis group & 1 & 0.0048 \\
\hline
\end{tabular}
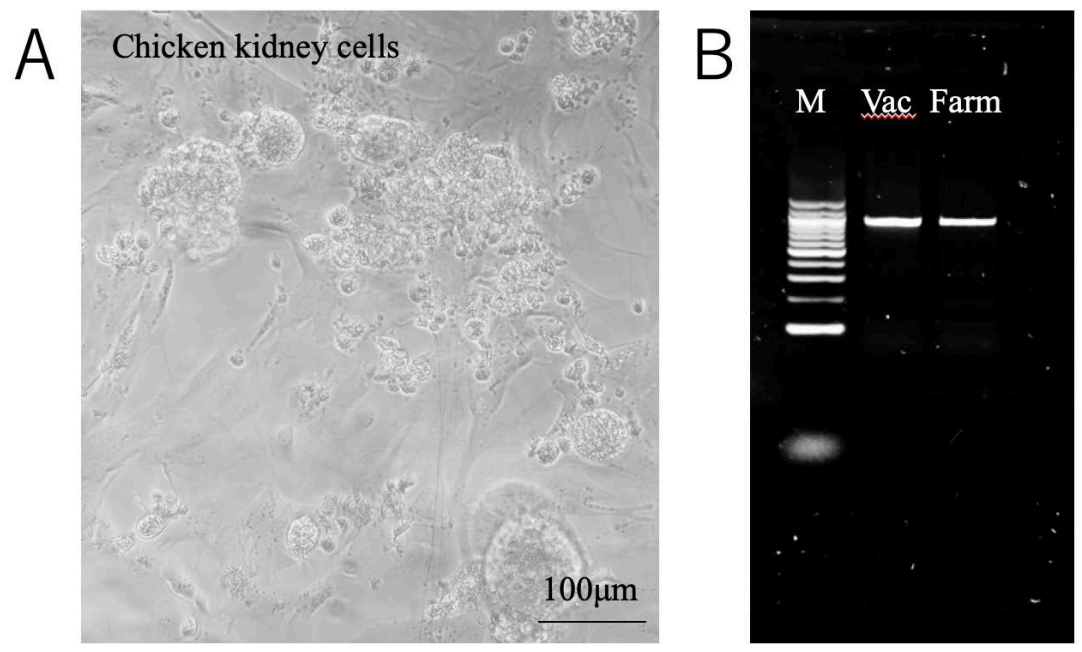

Figure 1. Chicken kidney cells inoculated with a cloaca swab from dead chickens from an Indonesian poultry farm. Cytopathic effects were observed at two days after the inoculation (A). PCR using ND-specific primers showed a single clear band around $900 \mathrm{bp}$ in the products from both the vaccine strain of NDV and the chorioallantoic fluid from a cloaca swab; the farm chicken sample was found to be NDV. M, marker of a 100-bp ladder, Vac, vaccine strain of NDV; Farm, chicken cloaca swab sample from poultry farm. 


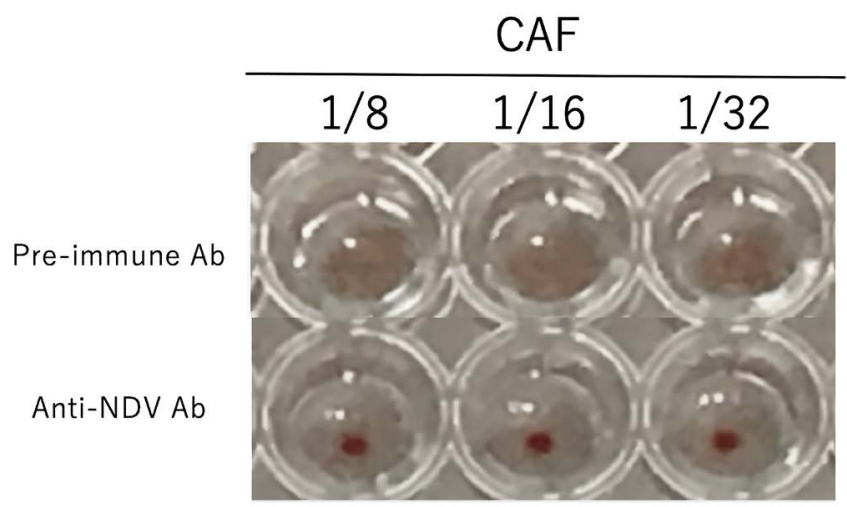

Figure 2. HA test using chicken erythrocytes. The chorioallantoic fluid (CAF) (diluted 8to 32-fold) after injection with a cloacal swab was mixed with erythrocytes in the wells of a microplate. Hemagglutination was observed with the pre-immune antibody (Ad) as a negative control antibody (A). However, the addition of a specific antibody against NDV (anti-NDV Ab) blocked hemagglutination (B). Accordingly, CAF was found to contain amplified NDV.

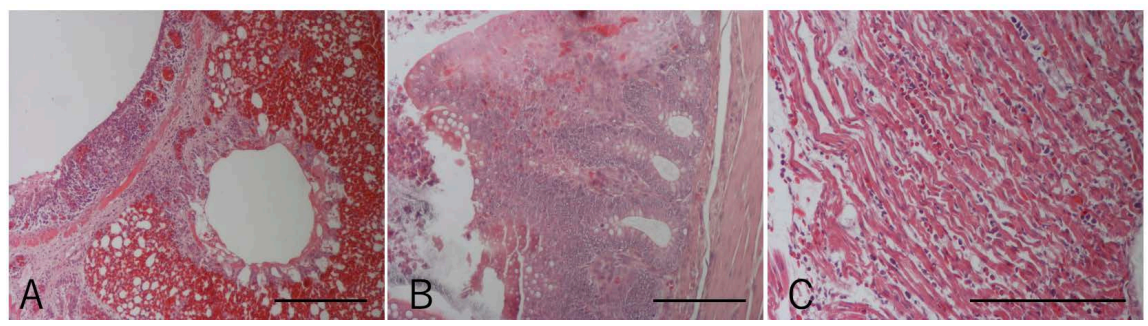

Figure 3. Histopathological findings of chicken lung, intestine and myocardium inoculated intranasally with ND field strain. In the lung, necrosis of the tracheal mucosal epithelium and inflammatory cell infiltration (mainly heterophils), inflammation accompanied by high hyperemia and congestion of the lung, and cell debris and mucus are observed in the lumen of the para-bronchi (A). In the heart, marked inflammation is observed with mucosal epithelial necrosis and heterophil infiltration (B). In the heart, extensive myocardial necrosis and interstitial inflammatory cell infiltration (such as heterophils) are observed (C). Bar, $100 \mu \mathrm{m}$.

\section{Effects of $B X$-1 intake on $N D$ in chickens}

Viral solution (8 HA) of NDV farm strain was inoculated into the nasal cavity of 10-day-old chickens, and the number of deaths was counted for the next 10 days, with or without BX-1. As a result, the mortality rate of ND-infected chickens drastically changed in the flock fed the BX-1 diet for one week before virus inoculation (Figure 4). Even the lowest dose of BX-1 at $0.02 \%$ exerted an inhibitory effect on mortality. Furthermore, higher doses of BX-1 tended to slow the deaths of birds. Given the lack of any marked differences in the mortality among BX-1 dosages at day 10 , implementation of BX-1 for practical use at a poultry farm was considered feasible even at a dose of $0.02 \%$, with consequent cost reduction expected. Since $0.2 \%-0.5 \%$ BX-1 is used as the commercial products to prevent Salmonella colonization in chicken intestinal tracts, this commercial product is effective on the prevention for chickens by both bacterial and viral infections [14]. 


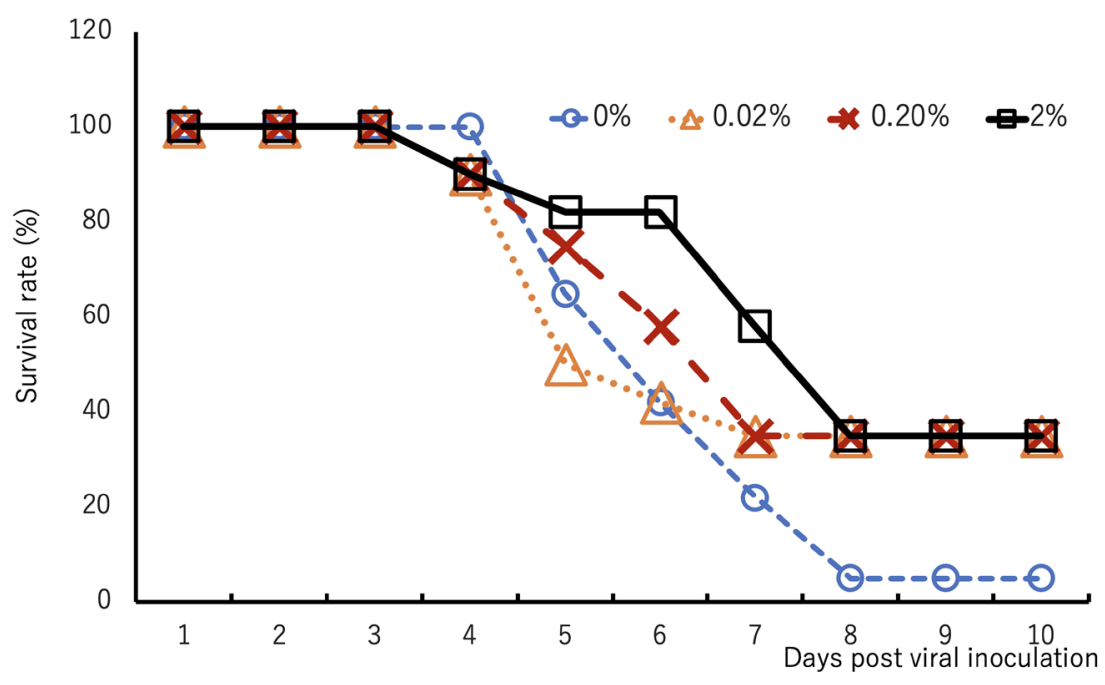

Figure 4. Effect of diet mixed with BX-1 on the survival of NDV field-infected chickens. BX-1 formulations $(0 \%, 0.02 \%, 0.2 \%, 2 \%)$ were fed freely to chickens, and 1 week later, NDV field strains were inoculated intranasally into the chickens. The survival rates up to 10 days after virus inoculation are indicated in the graph.

\section{Discussion}

One particularly interesting and potentially important finding from this study was the observation that BX-1, a soil microbial EM agent, was able to control not only bacterial infections, but also viral infections: the intake of soil bacterial preparation BX-1 reduced the mortality rate of chickens infected with highly pathogenic NDV. Soil bacterial EM preparations can be mass-produced, are excellent for storage and transportation and can be supplied at low cost [13]. Therefore, EM is considered useful as a feed additive for livestock.

Since ND is a viral disease and thus operates differently from bacterial diseases, the soil bacterial preparations were unlikely to have contributed directly to the suppression of pathogen colonization in the gastrointestinal tract. Soil bacteria might therefore improve the biological function of chickens and suppress viral infection or reduce the disease severity as found in human atrophic dermatitis [9] [10] [14]. Indeed, there have been reports that the intake of lactic acid bacteria suppresses the flu virus, suggesting a relationship between the microflora in the digestive tract and immunity: the ingestion of bacteria is thought to activate natural killer (NK) cells, resulting in the suppression of virus infection and relief of symptoms [7] [8]. More detailed cellular and molecular analyses will be required in order to verify the mechanism underlying the ND-suppressive effects of the soil bacterial group BX-1.

In nature, birds commonly ingest soil and thereby consume various microorganisms from the environment. In poultry, however, breeding conditions lacking any windows or having only half-windows are becoming increasingly common, and therefore chickens often no longer consume soil. The construction of a ground-based poultry farming system might be useful as a countermeasure against infectious diseases. 


\section{Conflicts of Interest}

The authors declare no conflicts of interest regarding the publication of this paper.

\section{References}

[1] Macpherson, L.W. (1956) Some Observations on the Epizootiology of Newcastle Disease. Canadian Journal of Comparative Medicine and Veterinary Science, 20, 155-168.

[2] Mase, M., Imai, K., Sanada, Y., Sanada, N., Yuasa, N., Imada, T., Tsukamoto, K. and Yamaguchi, S. (2002) Phylogenetic Analysis of Newcastle Disease Virus Genotypes Isolated in Japan. Journal of Clinical Microbiology, 40, 3826-3830. https://doi.org/10.1128/JCM.40.10.3826-3830.2002

[3] Alders, R. and Peter, S. (2001) Controlling Newcastle Disease in Village Chickens: A Field Manual. ACIAR, Canberra.

[4] Ganar, K., Das, M., Sinha, S. and Kumar, S. (2014) Newcastle Disease Virus: Current Status and Our Understanding. Virus Research, 184, 71-81.

https://doi.org/10.1016/j.virusres.2014.02.016

[5] Adachi, K., Handharyani, E., Sari, D.K., Takama, K., Fukuda, K., Endo, I., Yamamoto, R., Sawa, M., Tanaka, M., Konishi, I. and Tsukamoto, Y. (2008) Development of Neutralization Antibodies against Highly Pathogenic H5N1 Avian Influenza Virus Using Ostrich (Struthio camelus) Yolk. Molecular Medicine Reports, 1, 2003 2009.

[6] Tsukamoto, Y., Nakano, Y. and Adachi, K. (2018) Protection against Infectious Bronchitis Virus, a Corona Virus Infection, Using Ostrich Antibodies. Health, 10, 1294-1308. https://doi.org/10.4236/health.2018.1010100

[7] Kinoshita, T., Maruyama, K., Suyama, K., Nishijima, M., Akamatsu, K., Jogamoto, A., Katakami, K. and Saito, I. (2019) The Effects of OLL1073R-1 Yogurt Intake on Influenza Incidence and Immunological Markers among Women Healthcare Workers: A Randomized Controlled Trial. Food \& Function, 10, 8129-8136. https://doi.org/10.1039/C9FO02128K

[8] Kumova, O.K., Fike, A.J., Thayer, J.L., Nguyen, L.T., Mell, J.C., Pascasio, J., Stairiker, C., Leon, L.G., Katsikis, P.D. and Carey, A.J. (2019) Lung Transcriptional Unresponsiveness and Loss of Early Influenza Virus Control in Infected Neonates Is Prevented by Intranasal Lactobacillus rhamnosus GG. PLoS Pathogens, 15, e1008072. https://doi.org/10.1371/journal.ppat.1008072

[9] Kim, W.K., Jang, Y.J., Han, D.H., Seo, B., Park, S., Lee, C.H. and Ko, G. (2019) Administration of Lactobacillus fermentum KBL375 Causes Taxonomic and Functional Changes in Gut Microbiota Leading to Improvement of Atopic Dermatitis. Frontiers in Molecular Biosciences, 6, 92. https://doi.org/10.3389/fmolb.2019.00092

[10] Kim, I.S., Lee, S.H., Kwon, Y.M., Adhikari, B., Kim, J.A., Yu, D.Y., Kim, G.I., Lim, J.M., Kim, S.H., Lee, S.S., Moon, Y.S., Choi, I.S. and Cho, K.K. (2019) Oral Administration of $\beta$-Glucan and Lactobacillus plantarum Alleviates Atopic DermatitisLike Symptoms. Journal of Microbiology and Biotechnology, 29, 1693-1706. https://doi.org/10.4014/jmb.1907.07011

[11] Weinack, O.M., Snoeyenbos, G.N., Smyser, C.F. and Soerjadai, A.S. (1982) Reciprocal Competitive Exclusion of Salmonella and Escherichia coli by Native Intestinal Microflora of the Chicken and Turkey. Avian Diseases, 26, 585-595. https://doi.org/10.2307/1589905 
[12] Bailey, J.S. (1987) Factors Affecting Microbial Competitive Exclusion in Poultry. Food Technology, 41, 88-92.

[13] Mead, G.O. and Impey, C.S. (1987) The Present Status of the Nurmi Concept for Reducing Carriage of Food-Poisoning Salmonellae and Other Pathogens in Live Poultry. In: Smulders, F.J.M., Ed., Elimination of Pathogenic Organisms from Meat \& Poultry, Elsevier, 57-77.

[14] (1997) Effects of BX-1 on Salmonella Infected in Hatched Chickens and Laying Hens. Yamaguchi Institute of Cell Biology, 1-8. 